\title{
Extent of Utilization Of Analytical Techniques And Substantive Test By Accounting Staff For Fraud Detection In Large Scale Business Organisations In Delta State
}

\author{
Prof. J. I. Ezenwafor \\ Department of Technology and Vocational Education, \\ Faculty of education. Nnamdi Azikiwe University, Awka. \\ Frank O. Udukeke ( Ph.D) \\ Department of Business Education, \\ Faculty of Education, University of Uyo, Akwa Ibom State
}

\begin{abstract}
This study on extent of utilization of analytical techniques and substantive test by accounting staff for fraud detection in large scale business organisations in Delta State was necessitated by the growing incidence frauds that are crippling businesses and socio-economic development of the state. Two research questions guided the study and two null hypotheses were tested. Related literature to the study were reviewed. Descriptive survey research design was adopted for the study. The population of the study was 260 accounting staff. A sample size of 160 was drawn for the study using stratified sampling technique. A four-point rating scale questionnaire developed by the researchers containing 23 items in two clusters was used for data collection. Internal consistency method was used to determine the reliability of the questionnaire with Cronbach Alpha and this yielded reliability coefficient values of 0.91 and 0.84 respectively for the sections with an overall reliability of 0.88 . Data were analyzed using mean and standard deviation to answer the research questions and determine the homogeneity of the respondents' view while t-test and analysis of variance were used to test the hypotheses at 0.05 level of significance. The results showed that the accounting staff moderately utilized analytical technique for fraud detection but highly utilized substantive test. Furthermore, it was found that types and status of organization in NSE did not significantly influence the respondents' ratings. Based on the findings of the study, it was concluded that the accounting staff are not adequately utilizing techniques that could facilitate fraud detection in large-scale business organisations as required to combact the menance. It was therefore recommended among others, that, management of LSBOs should sponsor their accounting staff on training and that sharesholders should insist that the techniques are adequately utilized by holding the management accountable for future incidence of fraud.
\end{abstract}

Keywords: auditing techniques, fraud detection and large-scale business organisation

\section{INTRODUCTION}

Large-scale business organisations constituted the main stabilizing force in Delta State economy in the 1970's and early 1980's. These business organisations provided employment for the people, market for the raw materials of small scale producers, high quality goods and services, revenue to the government as well as social amenities. Large-scale business organisations have a great deal of political and economic power. Telsang, in 2009, observed that some organisations are so large that they have more influence on the economy than the government in power. In another development, Shubin (2007) stated that, the sales and revenues of some big companies are bigger than the economies of several small countries. Large-scale business organisations are able to produce goods and render services in bulk and 
at low cost, because they have the financial means to pay for the required technology and large number of qualified staff needed to produce the goods or render the services.

Indubitably, large-scale business organisations help in the conservation of foreign exchange and raising of standard of living. In 2010, Jimah posited that business enterprises help in the provision of quality goods and services. Some of the quality goods produced locally are often consumed within the country, while others are exported to other countries for the purpose of earning foreign exchange. Egboh (2009) asserted that business organisations help in the reduction of inflation rate by providing goods and services at affordable prices. Egboh stated further that business organisations facilitate the redistribution of income within an economy. However, observation by the reseachers have shown that there are persistent and rampant occurrence of fraud in large-large business organisations in Delta State.

Public and private organisations in Nigeria are deeply soaked in and characterized by fraud. Fraud has been described as the worst enemy of businesses in the past and in the present (Hamilton \& Gabriel, 2012). There is rarely a week that passes without the report of fraud or other fraudulent activities being in Nigerian newspapers. Comprehensive fraud statistics are difficult to come by because government agencies and companies tend to keep records of only those frauds that affect their area(s) of interest. All fraud statistics are based on known frauds and any number that is quoted is considered to be only a tip of the iceberg (Silverstone \& Sheetz, 2007). Below are some of the fraud headlines in national dailies in very recent times. Outrage over High Level of Fraud in Nigeria's Financial System (Bassey, 2012); Nigeria Lost N16tr to Scams in Oil and Gas Sector, says report (Ogidan, 2012); KPMG: Nigeria, Most Fraudulent Country in Africa (Edolo, 2012); Banks Recorded N28bn Fraud Case in 2011 (Onuba, 2012); Powerful Nigerian “Godfathers" Behind Pension Scam (Ekott, 2012); Pension Scam in Nigeria: Role of Regulators (Takor, 2012); Ajudua Remanded in Prison Over Alleged \$1.69m Fraud (Nwannekanma, 2013); 32 Billion Pension Fraud: What a Country! (Austine, 2013).

Aigienohuwa, Okoye and Uniamikogba (2017) averred that fraud is an economic and social menace with adverse multiplier consequences on individuals, organisations and the society at large. The costs of fraud are passed on to society in the form of increased customer inconveniences, loss of jobs, opportunity costs, abandoned projects, unnecessarily high prices of goods and services and criminal activities funded with fraudulent gains (Ijeoma \& Aronu, 2013). Osisioma (2012) contended that fraud has penetrated the warp and woof of the Nigerian society. The boss and his messenger, the police officer and the recruit, the classroom teacher and his students, the politician and the voters, the judge and the lawyer, the pastor and the parishioner - only a negligible few can remain untainted by fraud.

Fraud affects the economic development of a nation. Basin (2013) submitted that fraud affects local, national and international economies. The primary effect of fraud is the loss of money or property by the victim. Osisioma (2012) opined that many of the businesses in liquidation have suffered a great deal of fraud. As a result, some businesses record monumental losses which rock their foundations. Fraud does not only dampen economic growth and development, but also affects the inflow of Foreign Direct Investment (FDI) negatively (Lee and Oh, 2007). Fraud has the capacity of reducing a business organisation's patronage and reputation. When fraudulent practices thrive in an organisation, there will be the tendency that customers will be dissatisfied. The Institute of Internal Auditors (2016) asserted that fraud negatively impacts organisations in many ways including financial, reputation, psychological and social implications. The body stated further that the full cost of fraud is immeasurable in terms of time, productivity, reputation and customers' relationship. Depending on the severity of the 
loss arising from fraud, an organisation can be irreparably harmed. Fraud in public organisation has the capacity to affect the social well-being of the general public; it dwindles the fortunes of public organisations and takes resources away from the needy. To detect fraud in business organisation, financial records of an organisation have to be audited regularly, accounting staff should utilize several technqiues such as the analytical technique and substantive test.

An analytical technique has the overall objective of identifying the unexpected relationship that seems not to make sense initially. Because of this attribute, it may be useful at the start of an investigation to aid in developing a logical scope. As an investigation progresses and more becomes known about schemes and perpetrators, an analytic procedure can be used to identify areas for further review and inquiry. Okoye, Maimako, Jugu and Jat (2017) asserted that the number of transactions in a business often prohibits the ability to examine every piece of paper and underlying action taken in relation to a particular transaction. Analytic technique will therefore be needed to focus on the problem areas in certain segments of the financial statements to detect and prevent fraud. Analytic procedure is the name used for a variety of techniques the forensic auditor can use to assess the risk of material misstatement in financial records (Othman, Aris, Mardziyah, Zainan \& Amin, 2015). This procedure involves the analyses of trends, ratios, and reasonableness tests derived from an entity's financial and operating data.

Substantive tests could help in detecting fraud in different aspect of business transactions in an LSBO. According to Adeniyi (2012), the areas include non-current assets, debentures, loan stock, bank loans, finance lease, accruals, provisions and contingencies. Substantial fraud could be detected through substantive test. Substantive tests are intended to create evidence that a auditor will assemble to support the assertion that there are no material misstatements as regard the completeness, validity and accuracy of the financial records of an entity. Thus, substantive procedures are performed by an auditor to detect whether there are material misstatements in financial transactions. Millichamp and Taylor (2012) explained that a substantive test is the process, step or procedure that creates conclusive evidence regarding the completeness, existence, disclosure, valuation of assets or accounts in the financial statements.

Substantive tests include testing classes or transactions, account balances and disclosures, comparing financial statements and accompanying notes to the underlying accounting records, journals entries and other adjustments made during the preparation of the financial statements. It is against this background that the study was conceived to determine the extent of utilisation of forensic auditing investigation techniques for fraud detection in LSBOs in Delta State of Nigeria.

It is worrisome that the incidences of fraud have become widespread and systemic in Nigeria generally and Delta State in particular (Osisioma, 2012). It persistent occurrence in these organisations has continued to elicit a lot of concerns and worries from well-meaning Deltans as it cripples businesses and socio-economic development of the state. Many of the companies have resorted to continuous downsizing of workforce for lack of sufficient profit to meet up with important financial obligations such as payment of salaries, corporate taxes, audit fees, dividend and others. This situation has thrown more Deltans into the already saturated labour market, which has increased the rate of unemployment and its attendant consequences in the state. The high rate of unemployment has made the state to witness unprecedented social vices such as kidnapping, cultism, pipeline vandalization and armed robbery incidents. This list is endless. it is in the light of the above problem that the study was conducted to determine the 
extent of utilization of analytical techniques and substantive test by accounting staff for fraud detection in large scale business organisations in Delta State.

\section{Purpose of the Study}

The main purpose of the study was to determine the utilisation of analytical techniques and substantive procedures by accounting staff for fraud detection in large scale business organisations in Delta state. Specifically, the study determined the extent of utilisation of:

1. substantive test for fraud detection in large-scale business organisations in Delta State.

2. analytic technique for fraud detection in large-scale business organisations in Delta State;

\section{Research Questions}

The following research questions guided the study:

1. What is the extent of utilisation of substantive test for fraud detection in large-scale business organisations in Delta State?

2. What is the extent of utilisation of analytic technique for fraud detection in large-scale business organisations in Delta State?

\section{Hypotheses}

The following null hypotheses were tested at .05 level of significance.

1. There is no significant difference in the mean ratings of respondents from manufacturing, trading or service large-scale business organisations on the extent of utilisation of substantive tests for fraud detection.

2. Respondents do not differ significantly in their mean ratings on utilisation of substantive tests for fraud detection based on the status of organisation in the Nigerian Stock Exchange.

3. There is no significant difference in the mean ratings of respondents from manufacturing, trading or service large-scale business organisations on the extent of utilisation of analytical technique for fraud detection.

4. Respondents do not differ significantly in their mean ratings on utilisation of analytical technique for fraud detection based on the status of organisation in the Nigerian Stock Exchange.

\section{REVIEW OF LITERATURE}

Fraud is a toxic virus that has characterized both private and public institutions globally. Fraud is a complex social, political and economic phenomenon that is ubiquitous in both public and private sectors in varying degrees and magnitudes. Skalak, Alas and Sellitto (2015) asserted that fraud is a feature of every organized culture in the world. It is difficult to quantify the magnitude of fraud losses since majority of fraud cases go undetected and unreported (Bhasin, 2013). It affects many organisations, regardless of size, location or industry. According to ACFE (2010), approximately 160 billion was lost by United States' companies in 2004 due to occupational fraud and abuse, and nearly one in six cases cost the organisation in excess of 1 million dollars. By the same token, 42.5 percent of European companies fell victim to fraud in 2000 and 2001 and the average cost of fraud was 6.7 million pounds (Skalak, Alas \& Sellitto, 2015). Globally, fraud accounts for 5\% of Gross Domestic Product (GDP), equivalent to about 3.8 trillion dollars (ACFE, 2015), while organisations around the world lose an estimated 5\% of their manual revenue to fraud, a figure that translates to a potential total fraud loss of more than 4 trillion dollars (Transparency International, 2016). Okoye (2016) stated that fraud is a problem that has impacted on both large and small business organisations. Fraud affect the general public who indirectly pay for the losses arising from fraudulent activities through the increased cost of goods and services. 
Bhasin (2013) presented a list of numerous financial frauds and scandals with historical significance from both the developed and developing nations. Some of these scandals include Global Crossing (Bermuda), Nortel Network (Canada), Vivendi Universal (France), Adelphia Communication, IBM, Enron, Xerox, Lehman Brothers (USA), United Engineers Bhd (Malaysia), Wiggins, Versailles (UK), Samsung Electronics (Korea), Halliburton scandal among others.

The fraud problem continues to plague organisations and stakeholders around the world (Ravisankar, Ravi, Raghava, Rao \& Bose 2011). The Association of Certified Fraud Examiners (ACFE, 2010) in its report to the nations on occupational fraud and abuse, found that financial statement fraud, though less than 5 per cent of total fraud cases reported, averaged about 1.7 million dollars per incident. This was by far the most costly of all types of fraud. By implication, the figure translated to an annual loss of more than 3.5 trillion dollars when applied to the 2011 Gross World Product. Similarly, the Committee for Sponsoring Organisations of the Treadway Commission fraud report (2010) in their report of 347 cases of fraud from 1998 to 2007 discovered that an average dollar amount of each occurrence of fraud had increased from 4.1 million dollars in 1999 to 12 million dollars in 2007. In the United Kingdom, the scale of loss in 2012 against a victim is about 73 billion pounds annually and has been on the increase (National Fraud Authority (UK), Annual Fraud Indicator, 2012).

In India, fraud losses amounted to 66 billion between 2011 and 2012 (The Ernest \& Young's India Fraud Indicator), while fraud loss in Nigeria for 2012 alone was more than 1.5 billion dollars (KPMG, 2012). The damage done by fraud can better be imagined than experienced and when fraud is discovered, it is always a surprise for the business to believe because it is always so much that they may be forced to believe that such a loss did not occur. In most cases, fraud is rarely reported due to the negative impact or the risk of embarrassment and reduction in the level of confidence by customers or shareholders (KPMG, 2012). This may lead to inability to say emphatically how much has been lost to fraud. However, the estimated amount of fraud related losses reached $\$ 650$ billion in 2006 (Wells, 2007).

\section{RESEARCH METHOD}

The descriptive survey design was adopted for this study. The study was conducted in Delta State. The choice of Delta State for this study was informed by the fact that many large-scale business organisations operating there have wound-up in recent times and it appears that increase in fraudulent activities is one of the major factors responsible for this ugly situation. The population for the study comprised all the 268 accounting staff (manufacturing organisations -108 , trading organisations -75 and service organisations -85 ) in all the 30 large-scale business organisations in Delta State (Corporate Affairs Commission/Managers of Large-Scale business organisations, 2018). Stratified simple random sampling technique was used to drawn 160 (manufacturing organisations - 62, trading - 50, service - 48) was used for the study. This sample size was derived statistically using Taro Yamane formulae. A 4-point rating scale questionnaire titled "Analytical Technique and Substantive Test for Fraud Detection Questionnaire (ATSTFDQ)" containing 23 items of A and B was used for data collection for the study. The instrument was developed by the researcher based on the research questions guiding the study and insight from reviewed literature. Section A contains three items on the personal data of the respondents while section B was split into two clusters of B1 and B2. Section B is a four-point response scale of Highly Utilised (HU) - 4 points, Moderately Utilised (MU) - 3 points, Lowly Utilised (LU) - 2 points and Not Utilised (NU) - 1 point.

The instrument was subjected to face-validity by three experts; one from Nnamdi Azikiwe University, Awka and the other two from the University of Uyo. The internal consistency of the 
instrument was determined using Cronbach Alpha and this yielded reliability coefficient values of 0.91 and 0.84 respectively for the sections with an overall reliability of 0.88 . The questionnaire was administered on the respondents by the researcher with the help of two research assistants who were briefed on the procedures to follow. Out of the 160 copies of questionnaire administered on the respondents, 156 copies representing 98\% were retrieved and used for analysis.

Mean and standard deviation were used to answer the research questions and ascertain the closeness of the respondents' means. Decision on the research questions were based on the cluster mean relative to the real limits of numbers shown below:

\section{Response 0ptions}

Highly Utilised (HU)

Moderately Utilised (MU)

Lowly Utilised (LU)

Not Utilised (NU)

Values
4
3
2
1
Real Limit
$3.50-4.00$
$2.50-3.49$
$1.50-2.49$
$0.50-1.49$

Analysis of Variance (ANOVA) and independent t-test were used to test the null hypotheses at 0.05 extent of significance. A null hypothesis was rejected where the p-value was less than or equal to the alpha extent of 0.05 otherwise it was not rejected.

\section{RESULTS}

Table 1

Respondents' Mean Ratings on the Extent of Substantive Test For Fraud Detection in Large-Scale Business Organisations in Delta State.

\begin{tabular}{|c|c|c|c|c|}
\hline & & & & $=156$ \\
\hline $\mathrm{S} / \mathrm{N}$ & Substantive tests & Mean & SD & Remarks \\
\hline 1 & $\begin{array}{l}\text { Test of procedures in place for determining carrying } \\
\text { amount of non-current assets }\end{array}$ & 3.73 & .87 & $\mathrm{HU}$ \\
\hline 2 & Check of amortization calculations for accuracy & 3.51 & 1.13 & HU \\
\hline 3 & Check of calculation of the purchase of goodwill & 3.98 & .87 & HU \\
\hline 4 & $\begin{array}{l}\text { Confirmation of consideration paid for the business } \\
\text { acquired. }\end{array}$ & 3.33 & .77 & MU \\
\hline 5 & Verification of total charge for depreciation & 3.61 & .92 & HU \\
\hline 6 & Check of depreciation calculations for accuracy. & 2.94 & .83 & MU \\
\hline 7 & Review of gains on sales disposal & 3.80 & .81 & HU \\
\hline 8 & Review of depreciation rates for reasonableness & 2.93 & .81 & MU \\
\hline 9 & $\begin{array}{l}\text { Check of balances obtained from the count against the } \\
\text { client's cash records }\end{array}$ & 3.98 & .79 & HU \\
\hline 10 & $\begin{array}{l}\text { Comparing cashbook balance with bank statement } \\
\text { balance }\end{array}$ & 3.70 & .46 & HU \\
\hline 11 & Checking for right in respect of non-current assets & 3.72 & .98 & HU \\
\hline & Cluster Mean & 3.57 & & HU \\
\hline
\end{tabular}

Table 1 shows that eight of the items had mean ratings ranging between 3.51 and 3.98 which means that they are highly utilised while the remaining three items had mean ratings ranging between 2.93 and 3.33 which means they are moderately utilised. The cluster mean score of 3.57 shows that substantive test is highly utilised for fraud detection in large-scale business organisations in Delta State. The standard deviation range for all the items is low showing that the respondents were homogeneous in their views. 
Table 2

Respondents' Mean Ratings on the Extent of Utilization of Analytical Technique for Fraud Detection in Large-Scale Business Organisations in Delta State.

\begin{tabular}{|c|c|c|c|c|}
\hline & & & & 156 \\
\hline $\mathrm{S} / \mathrm{N}$ & Analytical Techniques & Mean & SD & Remarks \\
\hline 1 & $\begin{array}{l}\text { Comparison of current period financial information } \\
\text { with prior period using ratio analysis }\end{array}$ & 3.09 & .82 & MU \\
\hline 2 & $\begin{array}{l}\text { Examination of relationships of financial information } \\
\text { of many years. }\end{array}$ & 3.12 & .79 & MU \\
\hline 3 & $\begin{array}{l}\text { Comparison of firms' financial information with } \\
\text { other firms in the same industry }\end{array}$ & 3.01 & .94 & MU \\
\hline 4 & $\begin{array}{l}\text { Benchmarking the results recorded in the financial } \\
\text { statements against an independent expectation }\end{array}$ & 1.86 & .77 & LU \\
\hline 5 & $\begin{array}{l}\text { Determination of percentage change in individual's } \\
\text { financial statement item over a period of time. }\end{array}$ & 2.72 & .98 & MU \\
\hline 6 & $\begin{array}{l}\text { Comparison of elements of financial statements } \\
\text { with a common base item. }\end{array}$ & 2.15 & .69 & LU \\
\hline 7 & Analysis of receipts from sales of goods & 3.02 & .79 & MU \\
\hline 8 & $\begin{array}{l}\text { Comparison of dividend received in different } \\
\text { periods }\end{array}$ & 2.96 & .81 & MU \\
\hline 9 & Analysis of payments to suppliers & 2.63 & .68 & MU \\
\hline 10 & Analysis of payment of taxes & 2.93 & .96 & MU \\
\hline 11 & Writing to bank to confirm account balances & 3.38 & .70 & MU \\
\hline 12 & Analysis of bad debts written-off & 1.86 & .77 & LU \\
\hline & Cluster Mean & 2.73 & & $\mathrm{MU}$ \\
\hline
\end{tabular}

Table 2 shows that 10 of the items had mean ratings ranging between 2.63 and 3.38 which means that they are modetaely utilised while the remaining two items had mean ratings of 1.86 and 2.15 which means they are lowly utilised. The cluster mean score of 2.73 shows that analytical techniqnue is moderately utilised for fraud detection in large-scale business organisations in Delta State. The standard deviation range for all the items is low showing that the respondents were homogeneous in their views.

\section{Testing of Hypotheses}

Table 3

ANOVA Summary of The Difference in the Mean Ratings of Respondents From Manufacturing, Trading or Service Large-Scale Business Organisations on the Extent of Utilisation of Substantive Tests for Fraud Detection.

\begin{tabular}{lcccccc}
\hline Sources of Variations & $\begin{array}{c}\text { Sum of } \\
\text { Squares }\end{array}$ & $\mathrm{df}$ & $\begin{array}{c}\text { Mean } \\
\text { Square }\end{array}$ & $\mathrm{F}$ & P-value & Decision \\
& 4.832 & 2 & 4.433 & & & \\
\hline Between Groups & & & & .936 & .235 & NS \\
& 83.392 & 153 & .544 & & & \\
Within Groups & 88.224 & 155 & & & & \\
Total & & & & &
\end{tabular}

Table 3 shows that the p-value of .235 is greater than the alpha extent of .05 with the degrees of freedom of 2 and 153 respectively. This means that there is no significant difference in the mean ratings of respondents from manufacturing, trading or service large-scale business organisations on the extent of utilisation of substantive tests for fraud detection. The null hypothesis was, therefore, not rejected. 


\section{Table 4}

t-test Analysis of the Difference In The Mean Ratings of Respondents on the Extent Of Utilisation of Substantive Tests for Fraud Detection Based on the Status of Their Organisations in the Nigerian Stock Exchange.

\begin{tabular}{lccccccc}
\hline Status in NSE & $\mathrm{N}$ & $\overline{\mathbf{X}}$ & $\mathrm{SD}$ & $\mathrm{Df}$ & t-cal & P-value & Decision \\
\hline Quoted $\mathrm{X}_{1}$ & 21 & 3.03 & .94 & & & & \\
& & & & 154 & 1.15 & .054 & NS \\
Unquoted $\mathrm{X}_{2}$ & 135 & 2.88 & .74 & & & & \\
\hline
\end{tabular}

Table 4 reveals that at .05 extent of significance with 154 degree of freedom, the P-value of .054 which is greater than the alpha extent of .05 is obtained. This means respondents do not differed significantly in their mean ratings on utilisation of substantive tests for fraud detection based on the status of their organisations in the Nigerian Stock Exchange (quoted/unquoted). The null hypothesis was, therefore, not rejected.

Table 5

ANOVA Summary of the Difference in the Mean Ratings of Respondents from Manufacturing, Trading or Service Large-Scale Business Organisations on the Extent Of Utilisation of Analytical Technique for Fraud Detection.

\begin{tabular}{lcccccc}
\hline Sources of Variations & $\begin{array}{c}\text { Sum of } \\
\text { Squares }\end{array}$ & Df & $\begin{array}{c}\text { Mean } \\
\text { Square }\end{array}$ & F & P-value & Decision \\
\hline Between Groups & 75.418 & 2 & 37.709 & & & \\
Within Groups & 27.268 & 153 & .179 & & .115 & NS \\
Total & 102.686 & 155 & & & & \\
\hline
\end{tabular}

Table 5 shows that the P-value of .115 is greater than the alpha extent of .05 with the degrees of freedom of 2 and 153 respectively. This means that there is no significant difference in the mean ratings of respondents from manufacturing, trading or service large-scale business organisations on the extent of utilisation of analytical technique for fraud detection. The null hypothesis was, therefore, not rejected.

Table 6

t-test Analysis of the Difference in the Mean Ratings of Respondents on the Extent of Utilisation of Background Investigation for Fraud Detection Based on the Status of Their Organisations in the Nigerian Stock Exchange.

\begin{tabular}{lccccccc}
\hline Status in NSE & $\mathrm{N}$ & $\overline{\mathbf{X}}$ & $\mathrm{SD}$ & $\mathrm{Df}$ & $\mathrm{t}$-cal & P-value & Decision \\
\hline Quoted $\mathrm{X}_{1}$ & 21 & 3.30 & .46 & & & & \\
& & & & 154 & -1.33 & .186 & NS \\
Unquoted $\mathrm{X}_{2}$ & 135 & 3.45 & .84 & & & & \\
\hline
\end{tabular}

Table 6 shows that at .05 extent of significance for 154 degree of freedom, the P-value of .186 which is greater than the alpha extent of .05 is obtained. This means that respondents do not differed significantly in their mean ratings on utilisation of analytical technique for fraud detection based on the status of their organisations in the Nigerian Stock Exchange (quoted/unquoted). The null hypothesis was, therefore, not rejected.

\section{DISCUSSION}

The findings revealed that substantive test was highly utilised for fraud detection in large-scale business organisations in Delta State. This finding is in agreement with the finding of Enofe, Omagbon and Ehigiator (2016) who found that the utilisation of substantive test significantly help in detection, prevention as well as reduction in incidences of fraud in business 
organisations. Substantive test is often deployed to ascertain occurrence, completeness, accuracy, cut-off, classification, existence, right, obligations and valuation in respect of classes of transactions, account balances, presentation and disclosure.

The findings also showed that there is no significant difference in the mean ratings of respondents from manufacturing, trading or service large-scale business organisations quoted or unquoted on the extent of utilisation of substantive test for fraud detection. However, the finding of Effiong (2013) showed a significant difference between the perceived effectiveness and actual usage of fraud prevention and detection mechanisms in Nigeria. Substantive test, when adequately performed enables a large-scale business organisation to detect material misstatement in figures, presentation and disclosures made in the financial statement.

The findings showed that analytic procedure is moderately utilised for fraud detection in largescale business organisations in Delta State. This finding is supported by the finding of Imoniana, Antynes, Mattos, and Maciel (2012) who found analytical procedure to be an effective technique in auditing. In addition, Ogutu and Ngahu (2016) found fraud prevention and detection to be an area that requires forensic accounting. The moderate utilisation of analytical procedure can be attributed to what Onodu, Okafor and Onyali (2015) finding revealed which is poor knowledge and perception of accounting personnel. Utilisation of analytic procedure involves evaluating and comparing financial and non-financial data for plausible relationships and investigating unexpected fluctuation. Previous year's gross profit percentage could be compared with current year's and ensuring that change is in line with expectation. It can also involve analysis of bad debts written off, assets, receipts from goods and tax paid.

The findings further showed that there is no significant difference in the mean ratings of respondents from manufacturing, trading or service large-scale business organisations quoted or unquoted on the extent of utilisation of analytic technique for fraud detection. This finding is related to the finding of Onodi, Okafor and Onyali (2015) which showed that there is a significant relationship between forensic investigation methods and corporate fraud deterrence. This means that the application of analytical technique can be used to detect fraud in large-scale business organisations.

\section{CONCLUSION}

From the findings of the study, it was concluded that accounting staff did not utilise the forensic auditing investigation techniques such as substantive test and analytical procedure for fraud detection in large-scale business organisations in Delta State as expected. As such, fraudulent activities like bribery, embezzlement, cash theft, inventory theft, cheque tempering, payroll scheme, swindle, forgery and kickbacks are causing incessant winding-up of large-scale business organisations in Delta State and these portend a no mean danger for socio-economic development of the state if not properly checked and nipped in the bud.

\section{RECOMMENDATIONS}

Based on the findings of the study, the following recommendations were made:

1. Accounting staff of large scale business organisations should always avail themselves of any training opportunity on forensic auditing investigation techniques in order to be more alert to fraudulent activities and prevent them.

2. Managers of large scale business organisations in Delta State should provide regular trainning for their accounting staff on analytical technique and other forensic auditing technique to enable them detect and nip fraud in the bud. 
3. Shareholders in large scale business organisations should insist that the techniques used in the study and other forensic auditing techniqnues are adequately utilized by holding and management accountable for fraud occcurences.

4. The Institute of Chartered Accountants of Nigerian should organize regular conference, seminars and workshops for their members where emerging trends in occurrence of frauds are highlighted to help professional accountants and auditors detect and prevent frauds or at least reduce the incidence to save their employers.

\section{References}

Adeniyi, A. A. (2012). Auditing and assurance services. Lagos: Value Analysis Consult.

Aigienohuwa, O. O. Okoye, E. I. \& Uniamikogbo (2017). Forensic accounting and fraud mitigation in the Nigerian banking Industry. International Accounting and Taxation Research Groff, 3(6), 177-195.

Association of Certified Fraud Examiners (2010). Introduction to fraud examination Retrieved fromhttps://www.acfe.com/uploadedFiles/Shared_Content/Products/Self-Study_CPE/Intro\%20to\%20FraudChapter\%20Excerpt.pdf.

Bassey, J. (2012, October 30). Outrage over high extent of fraud in Nigeria's financial system. Businessday, P. 9.

Bhasin, M. (2013). An Empirical investigation of the relevant skills of forensic accountants; Experience of a developing economy. European Journal of Accounting, Auditing and Fiancé Research, 1(2), 11-52

Efiong, E. J. (2012). Forensic accounting education: An exploration of extent of awareness in developing economies-Nigeria as a case study. International Journal of Business and Management.7(4), 26-34.

Egboh, S. H. O. (2009). Entrepreneurship Development for Employment and Wealth Generation. Benin City: EHIS Printers.

Ekpo, C. (2010). Introduction to auditing. Ikot -Ekpene: Termed publishers.

Golden, T. W., Skalak, S. L. \& Clayton, M. M. (2015). A guide to forensic Accounting investigation. New Jersey: John Wiley \& Sons Inc.

Hamilton, D. I., \& Gabriel, J. M. O. (2012). Dimensions of fraud in Nigeria quoted firms. Journal Social Science Management,3 (3), 112-120.

Igweonyia, O. V. (2016). Forensic accounting as a panacea to alleviation of fraudulent practices in Nigeria public sector organisations (A study of some selected ministries in Enugu State). International Journal of Management and Applied Science,2 (9), 183-188.

Ijeoma, N. \& Aronu, C. O. (2018). The Impact of fraud management on organisational survival in Nigeria. American Journal of Economics, 3 (10), 268-272.

Imoniana, J. O., Antynes, M. T. P, Mattos, S. M. \& Maciel, E. (2012). The analytical review procedure in audit: An exploratory study. Advances in Scientific and Applied Accounting, 2 (5), 282-303.

Institute of Chartered Accountants of Nigeria (2014). Auditing and assurance study Text. Berkshire: Amile wolf international.

Institute of Internal Auditors (2014). Practice advisory. Retrieved from http://www.theiia.org.

Jimah, M. S. (2010). Practice of Entrepreneurship. Benin City: Ribway Printers and Publishers Limited.

KPMG (2012). Fraud barometer - assess your risk before doing business. Journal of Business Research, 6 (5), 22 44.

Millichamp, A. \& Taylor, J. (2012) Auditing. Hampshire: Cengage Learning.

Nwannekanma, B. (2013, June 11). Ajudua reminded in prison over alleged \$1.69m fraud. Guardian, P.12.

Ogidan, A (2012, October 30) Nigeria lost N16tr to scam in oil and gas sector says report. Guardian. P.16.

Okoye, E.I. , Maimako, S. S Jugu, Y. G. \& Jat, R. B. (2017) Principles of fraud investigation on and forensic accounting. Awka: SCA Heritage Nigeria Ltd.

Onodi, B. E., Okafor, T. G. \& Onyali, C. I. (2015). The impact of forensic investigative methods on corporate fraud deterrence in banks in Nigeria. European Journal of Accounting, Auditing and Finance,3 (4), 69-85.

Onuba, I. (2012, November 29). Banks recorded N28bn fraud cases in 2011-Report. ThePunch. P.23. 
Osisioma, B. C. (2012). Combating fraud and white collar crimes: lessons from Nigeria. A paper presented at 2nd annual fraud andcorruption Africa Summit, held at Zanzibar Beach Resort, Zanzibar Republic of Tanzania, May 22.

Othman, R., Aris, N. A., Marziyah, A., Zainan, N. \& Amin, N. M-(2015). Fraud detection and prevention methods in the Malaysian public sector; Accountants and internal auditors' perception. Procedia Economics and Finance,28 (15), 59-67.

Ravisankar, P., Ravi, V., Raghava Rao, G., \& Bose, I. (2011). Detection of financial statement fraud and feature selection using data mining techniques. Decision Support Systems,50 (2), 491-500.

Shubin, V. A. (2007). Business management. London: Barnes and Noble Books.

Silverstone, H. \& Sheetz, M. (2007) Forensic accounting and fraud investigation for non-experts (2nd ed.). New Jersey: John Wiley and Sons, Inc.

Telsang, M. T. (2009). Introduction to business management. New Delhi: Chard Company Ltd.

Wells, J.T. (2008) Principles of fraud examination. Hoboken: Wiley, NJPublishers. 